\title{
Bacterial Isolates in ICU of A Tertiary Care Hospital in North East India: A Three Year Experience
}

\author{
Authors \\ Mrinal K Taye ${ }^{1}$, Subhankar Paul ${ }^{2}$, Neeta Dutta ${ }^{3}$ \\ ${ }^{1}$ Assistant Professor, ${ }^{2,3}$ Post Graduate Student, Department of Emergency Medicine \\ Gauhati Medical College and Hospital Guwahati, Assam. India \\ Corresponding Author \\ Mrinal Kanti Taye \\ Assistant Professor, Department of Emergency Medicine, Gauhati Medical College and Hospital \\ Guwahati, Assam. India.Pin-781032 \\ Email: taye.mrinal@gmail.com
}

\begin{abstract}
Introduction: The incidence of nosocomial infections in ICU is 4-5 times greater than in general ward. The study was to detect the pattern of bacterial isolates in ICU.

Methods: Specimens collected from respiratory tract, urine, blood and wound. The specimens collected sent to laboratory to identify the isolates.

Result: Respiratory tract infections were most prevalent with $79.5 \%$ followed by urinary tract (11.1\%), blood born infection (8.1) and wound infection 1.2\%. Gram negative infections like klebsiella, being the most frequent species with $54.6 \%$ followed by $E$ coli and pseudomonas $15.8 \%$ and $14.2 \%$ respectively.

Conclusion: Gram negative infections were the predominant cause of icu acquired infection in the region of North East India. Pattern and prevalence of bacterial isolates in icu tends to change with time.

Keywords: nosocomial infections, ICU, Gram negative infections, pattern changes.
\end{abstract}

\section{Introduction}

The incidence of nosocomial infections in ICU is 45 times greater than in general ward ${ }^{(1)}$. Critically ill patients are always at higher risk of developing nosocomial infections with resistant strains. Klebsiella, Pseudomonas, Acinetobacter, methicillin resistant Staphylococcus aureus (MRSA), vancomycin-resistant Enterococcus (VRE), Clostridium difficile, extended-spectrum $\beta$ - lactamase-producing GNB (ESBL) etc .Infections caused by these microorganisms increase hospital stay and attributes to high mortality, morbidity, financial burden ${ }^{(2,3)}$. The study was conducted to detect the pattern of bacterial isolates in ICU of a tertiary care hospital in north east India.

\section{Materials and Methods}

The present study was an observational retrospecttive data analysis on bacterial isolates and changing pattern of icu acquired infections. Study was conducted in Emergency ICU of Emergency Medicine Department. Gauhati Medical College and Hospital, Guwahati for three years from November 2013 to October 2016 and divided into three phases each comprising of twelve months. Phase 1: Nov 2013- Oct 2014 Phase 2: Nov 2014- Oct 2015 Phase 3: Nov 2015- Oct 2016 March 2003 to February 
2004. The study proposal was reviewed and approved by the institutional ethics committee of the hospital.

Selection of cases: Inclusion Criteria- Patients leucocytosis, shock with suggestive of septic etiology, increased amount \& purulence of tracheal secretions, hematuria, purulent surgical wounds) after staying 48hours or more in EICU with positive aerobic bacterial cultures were included in the study. Exclusion Criteria- Febrile / signs of infection on ICU admission staying less than 48 hours in the ICU. Transferred from another ICU. Positive cultures which were thought to be Contaminations $\&$ Commensals. All positive swabs of eye, ear, nose, throat and genital cultures. Positive fungal cultures were excluded from the study.

\section{Specimens collected were from Respiratory -}

Tracheal aspirate, ET tube tip, Sputum. Urine (including Foley's catheter tips). Blood (including Surgical wound, bed sores.

The specimens for antimicrobial sensitivity testing were studied by Gram stains and culture growth on nutrient, blood and MacConkey agar to identify the isolates. Antibiotic susceptibility testing was performed by disc diffusion method (modified Kirby Bauer method) on Muller Hinton agar (For all antimicrobials tested, MIC interpretive standards were defined according to CLSI breakpoints (Clinical and Laboratory Standard Institute) but study on antibiotic susceptibility pattern not included in the study.

\section{Results \& Observations}

Majority of the patients in the study were male with $66.1 \%$ with mean age of 48 years. Average icu stay of all patients were 18 days. Most of the patients were trauma $(32.4 \%)$ followed by neurological patients $(29.7 \%)$ in the form of stroke or other neurological disorders [table1]. Out of 1905 icu admissions in three years 1028 patients were eligible to be included in the study with inclusion and exclusion criteria and of which 138 patients came out to be culture positive. .Total culture positive samples were 161 as some patients showed developing signs \& symptoms of infections (fever, tip of central venous catheters). Wound swab from

positive culture from more than one site[ table2]. Respiratory tract gives positive isolate most abundantly with $79.5 \%$ followed by urine $11.2 \%$ blood $8.1 \%$ and wound infection $1.2 \%$ [ Fig 1,table 3]. Of total isolates $7.4 \%$ were gram positive cocci, predominantly staphylococcus $5 \%$ and $92.6 \%$ were gram negative bacilli in the form of klebsiella, being the most frequent species with $54.6 \%$ followed by e coli and pseudomonas $15.8 \%$ and $14.2 \%$ respectively. Bacteriology of respiratory tract infection shows klebsiella, pseudomonas, E coli, staph aureus, acinetobacter, proteus and citobacter. Urinary tract infections showed similar bacterial isolats but more of E coli $18 \%$ and enterococcus $2 \%$. Blood and urine also showed similar isolate more often klebsiella and E coli. [table 4,5,6,7,8]

Figure 1: pie diagram of different sites of icu acquired infections.

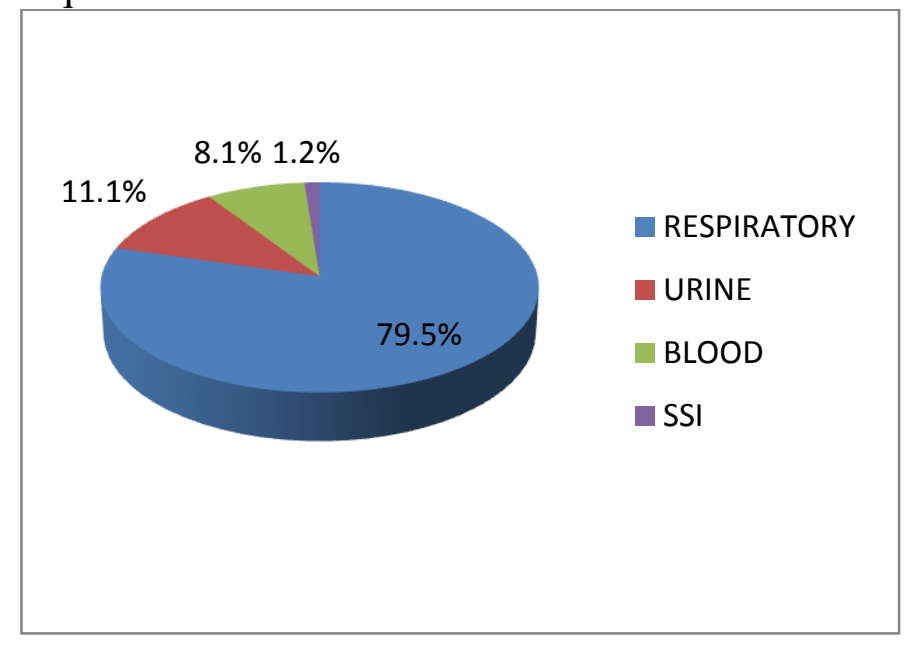

Table 1: Baseline characteristics of patients during three year period.

$\begin{array}{lc}\text { - Sex, male, } n(\%) & 680(66.1 \%) \\ \text { - Age, years (mean) } & 48.6 \pm 12.4 \\ \text { - Average length of ICU-stay, days } & 18.3 \pm 8.7 \\ \text { - Trauma } & 334(32.4 \%) \\ \text { - Neurological disorders } & 306(29.7 \%) \\ \text { - Immediate postoperative patient } & 95(9.2 \%) . \\ \text { - Pulmonary diseases, } & 66(6.4 \%) \\ \text { - Diabetes mellitus, } & 65(6.3 \%) \\ \text { - Undiagnosed diseases } & 55(5.3 \%) \\ \text { - Renal diseases } & 46(4.4 \%) \\ \text { - Cardiovascular diseases } & 41(3.9 \%) \\ \text { - Malignancy } & 20(1.9 \%) \\ \text { - } & \end{array}$




\section{JMSCR Vol||05||Issue||04||Page 20247-20252||April}

Table 2: Total number of icu admission with culture positive patients

\begin{tabular}{|l|c|c|c|c|}
\hline & Phase 1 & Phase 2 & Phase 3 & Total \\
\hline Total admitted patients & 578 & 662 & 665 & 1905 \\
\hline Included in study & 273 & 380 & 375 & $1028(53 \%)$ \\
\hline Culture positive isolates & $56(49)$ & $48(43)$ & $57(46)$ & $\begin{array}{c}161(138) \\
(15 \%)\end{array}$ \\
\hline
\end{tabular}

Table 3: Types of ICU acquired Infections

\begin{tabular}{|l|l|l|}
\hline SPECIMEN & Frequency & $\%$ \\
\hline RESPIRATORY & 128 & $79.5 \%$ \\
\hline URINE & 18 & $11.1 \%$ \\
\hline BLOOD & 13 & $8.1 \%$ \\
\hline WOUND & 2 & $1.2 \%$ \\
\hline TOTAL & 161 & $100 \%$ \\
\hline
\end{tabular}

Table 4: Etiological agents in infections acquired in ICU

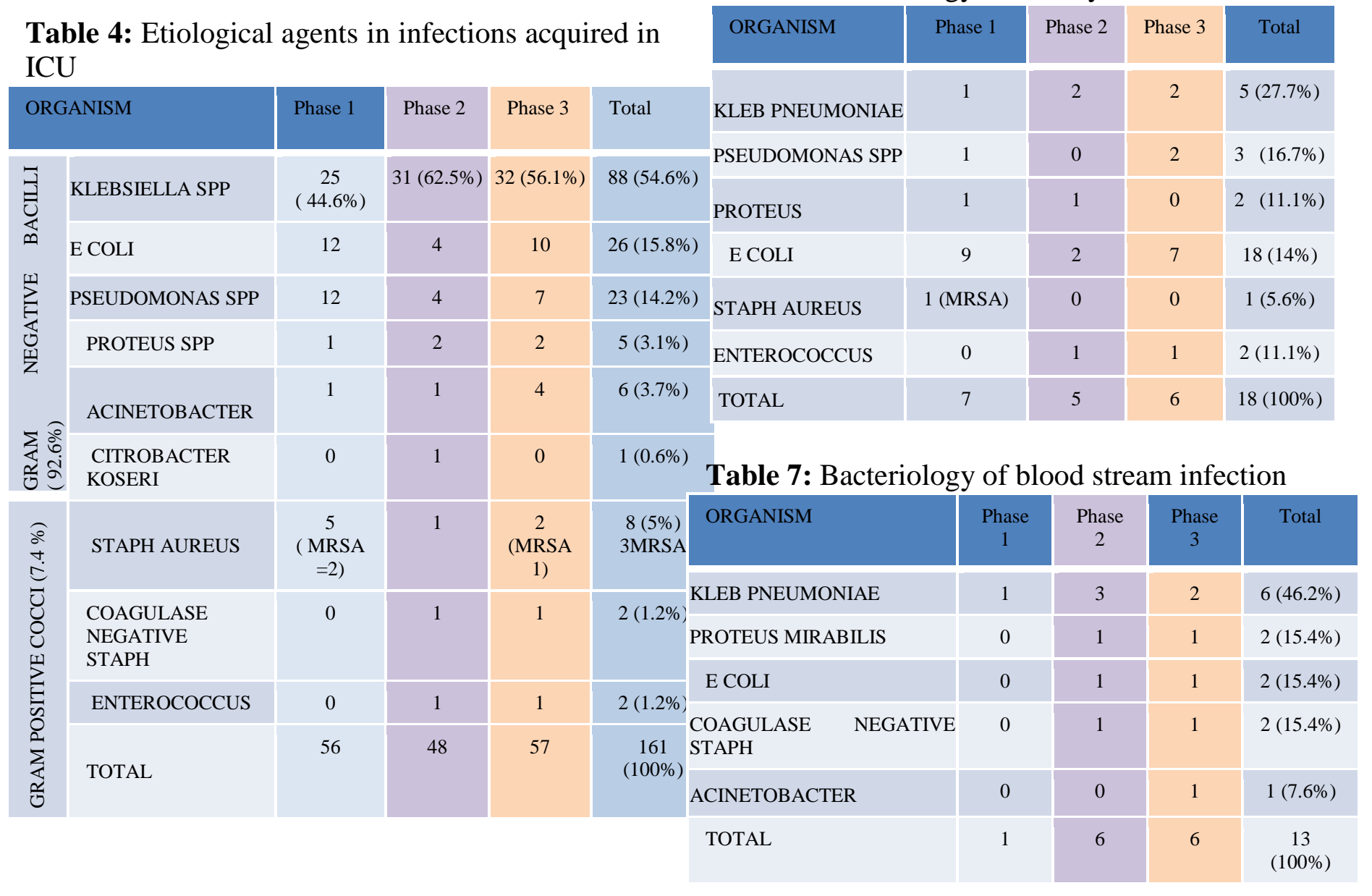

Table 8: Bacteriology of wound infection.

\begin{tabular}{|l|c|c|c|c|}
\hline ORGANISM & Phase 1 & Phase 2 & Phase 3 & Total \\
\hline KLEBSIELLA SPP & 0 & 1 & 0 & $1(50 \%)$ \\
\hline E COLI & 0 & 0 & 1 & $1(50 \%)$ \\
\hline TOTAL & 0 & 1 & 1 & $2(100 \%)$ \\
\hline
\end{tabular}

Table 5: Bacteriology of respiratory tract infection.

\begin{tabular}{|c|c|c|c|c|}
\hline ORGANISM & Phase 1 & $\begin{array}{l}\text { Phase } \\
2\end{array}$ & Phase 3 & Total \\
\hline KLEBSIELLA & 23 & 25 & 28 & $76(59.3 \%)$ \\
\hline PSEUDOMONAS & 11 & 4 & 5 & $20(15.6 \%)$ \\
\hline STAPH AUREUS & $\begin{array}{l}4 \\
(\text { MRSA } \\
=1)\end{array}$ & 1 & $\begin{array}{l}2 \\
(\mathrm{MRSA}=1)\end{array}$ & $\begin{array}{l}7 \text { ( MRSA } \\
\text { 2) }(5.4 \%)\end{array}$ \\
\hline E COLI & 3 & 1 & 1 & $5(27.7 \%)$ \\
\hline ACINETOBACTER & 1 & 1 & 3 & $5(3.9 \%)$ \\
\hline PROTEUS MIRABILIS & 0 & 0 & 1 & $1(0.7 \%)$ \\
\hline CITROBACTER & 0 & 1 & 0 & $1(0.7 \%)$ \\
\hline TOTAL & 48 & 36 & 44 & $\begin{array}{l}128 \\
(100 \%)\end{array}$ \\
\hline
\end{tabular}

Table 6: Bacteriology of urinary tract infection.

Table 7: Bacteriology of blood stream infection 


\section{Discussion}

Infections acquired during stay in the ICU is very common and inevitable because of reduced host defenses, invasive devices use, damage of anatomical barrier in the form of intubation, mechanical ventilation, frequent suctioning, catheterization etc and several drugs like sedatives, muscle relaxants, $\mathrm{H} 2$ blockers, over use of antibiotic itself create a predisposition for infections ${ }^{[4,5,6]}$.

The present study was an observational retrospecttive data analysis on bacterial isolates of icu acquired infections. The study was conducted in Emergency ICU of Emergency Medicine Department for three consecutive years. Trauma and neurological patients in the form of stroke were maximum with male predominance that received in our icu. ${ }^{[7,8]}$

Infection rate in the current study was $15.0 \%$. The ICU infection rates may vary between centers, depending on types of patients and icu, standard of laboratory, techniques of sample collection, diagnostic criteria etc. Current study was in single centre and for 3 consecutive year, bronchoalveolar lavage (BAL) or protected specimen brush (PSB) sample could not be collected as bronchoscope was not available. Many studies are multicentric and 1day point-prevalence study. So percentage of acquired infections in the ICU worldwide shows wide range from 9.6 to $48.7 \% .^{[9,10,11]}$. In the current study, intubation and mechanical ventilation, Foleys catheter and central venous catheter, were main source of infections. Invasive procedures, mechanical ventilation, prolong icu stay, inability to maintain proper nutrition etc have been reported as risk factors for mortality in many studies ${ }^{[12,13,14]}$

Respiratory tract infection is reported to be the most frequent site of infection in the ICU, followed by urinary tract and bloodstream infection respectively in the present study. Most of the patients were intubated or ventilated. Various studies showed pneumonia is predominant cause of icu acquired infection. ${ }^{[15,16,17,18,19]}$

Infection with multidrug resistant pathogens develops because of frequent use of broad spectrum antibiotics and causes an increase in morbidity, mortality, and economic burden. ${ }^{[20,21,22,23]}$.
Pseudomonas tends to be most resistant to treat followed by klebsiella, Acinetobacter baumannii and ecoli in our experience. ${ }^{[24,25]}$ The impact of increased length of ICU stay on nosocomial infections and mortality has been investigated in many studies. In the majority of the studies icuacquired infection was found to be an independent risk factor of increased length of icu stay. In this study, infection with klebsiella pneumoni followed by E coli, pseudomonas, staphylococcus and acinetobacter baumannii respectively were major causative organism. Tracheal aspirate harbor most of klebsiella and pseudomonas. Urine sample shows most of klebsiella and E coli. Here in our region of North East India klebsiella being most abundant isolates in icu similar to the majority of studies in which gram-negative organisms were the predominant agent and staphylococcus is still not a frequent isolate in our icu. Acinetobacter baumannii culture tends to increase gradually. ${ }^{[26,27,28,29,30]}$.

\section{Conclusion}

Gram negative infections were the predominant cause of icu acquired infection in the region of North East India. Pattern and prevalence of bacterial isolates in icu tends to change with time. Prolong icu stay, poor nutrition, invasive techniques are few causes that increases the chance of icu acquired infection. MDR organisms are increasing day by day. Antibiotic stewardship and strict infection control protocol particularly in ICU are need of the hour to prevent flaring up of antimicrobial resistance.

\section{Acknowledgements}

We would like to thank all data collectors and the participants in this study. No fund was available for this study.

\section{Declaration}

Conflicting Interests: The authors declare that they have no conflict of interest.

Financial Disclosure: No financial support was received. 


\section{References}

1. Kollef MH, Fraser VJ. Antibiotic resistance in intensive care unit setting. Ann Intern Med 2001; 134: 298-314.

2. Humphreys H, Winter B, Paul M. Infections in the adult intensive care unit: Springer Science \& Business Media; 2012.

3. Hosein IK, Hill DW, Jenkins LE, Magee JT. Clinical significance of emergence of bacterial resistance in the hospital environment. Sym Ser Soc J Appl Microbiol, 2002; 31: 90S-7S.

4. Ak O, Batirel A, Ozer S, Colakoglu S. Nosocomial infections and risk factors in the intensive care unit of a teaching and research hospital: A prospective cohort study. Med Sci Monit 2011;17:29-34.

5. Meric M, Willke A, Caglayan $\mathrm{C}$, et al. Intensive care unit-acquired infections: incidence, risk factors and associated mortality in a Turkish university hospital Jpn J Infect Dis 2005;58:297-302.

6. Appelgren P, Hellström I, Weitzberg E, et al. Risk factors for nosocomial intensive care infection: a long-term prospective analysis. Acta Anaesthesiol Scand 2001;45:710-719.

7. Yilmaz GR, Cevik MA, Erdinc FS, et al. The risk factors for infections acquired by cerebral hemorrhage and cerebral infarct patients in a neurology intensive care unit in Turkey. Jpn J Infect Dis2007;60:87-91.

8. Vincent JL, Rello J, Marshall J, Silva E, Anzueto A, Martin CD, et al. International study of the prevalence and outcomes of infection in intensive care units. JAMA 2009; 302(21): 2323-2329.

9. Pradhan NP, Bhat SM, Ghadage DP. Nosocomial infections in the medical ICU: a retrospective study highlighting their prevalence, microbiological profile and impact on ICU stay and mortality. J Assoc Physicians India 2014;62:18-21.

10. Shalini S, Kranthi K, Gopalkrishna Bhat K. Microbiological profile of nosocomial infection in the intensive care unit. J Clin Diagnostic Res 2010; 4(5): 3109-3012.
11. Erb A, Sturmer T, Brenner H. Prevalence of antibiotic resistance in Escherichia coli: overview of geographical, temporal, and methodological variations. Eur J Clin Microbiol Infect Dis 2007; 26: 83-90.

12. Mukhopadhyay C, Bhargava A, Ayyagari A. Role of mechanical ventilation and development of multidrug resistant organisms in hospital acquired pneumonia. Indian J Med Res.2003;118:229-35.

13. Winarto. Prevalence of extended-spectrum lactamases (ESBL)- bacteria of blood isolates in Dr. Kariadi Hospital Semarang 2004-2005. Media Medika Indosiana 2009; 43(5): 260-267.

14. Mehta A, Rosenthal VD, Mehta Y, Chakravarthy M, Todi SK, Sen N, et al. Device associated nosocomial infection rates in intensive care units of seven Indian cities: findings of the International Nosocomial Infection Control Consortium (INICC).

15. Hassandeh P, Motamedifar M, Hadi N. Prevalent bacterial infection in intensive care units of Shiraz University of Medical Science Teaching Hospital, Shiraz Iran. Jpn J Infect Dis 2009; 62: 249-253.

16. Chastre J, Fagon JY. Ventilator associated pneumonia. Am J Respir Crit CareMed.2002;165:867-903.

17. Gonlugur U, Bakici MZ, Akkurt I, Efeoglu T. Antibiotic susceptibility patterns among respiratory isolates of Gram negative bacilli in Turkish University Hospital. BMC Microbiol. 2004;4:32-4.

18. Ponce de LeónRosales SP, MolinarRamos F, DomínguezCherit $\mathrm{G}$, et al. Prevalence of infections in intensive care units in Mexico: a multicenterstudy. Crit Care Med 2000; 28:13161321

19. Esen S, Leblebicioglu H. Prevalence of nosocomial infections at Intensive care units in Turkey: a multicentre 1-day point prevalence study. Scan J Infect Dis 2004;36:144-148.

20. Blot S. Limiting the attributable mortality of nosocomial infection and multidrug 
resistance in intensive care units. Clin Microbiol Infect 2008;14:5-13.

21. Brusselaers N, Vogelaers D, Blot S. The rising problem of antimicrobial resistance in the intensive care unit. Ann Intensive Care 2011;1:47.

22. Katsaragakis S, Markogiannakis H, Samara E, et al. Predictors of mortality of Acinetobacte rbaumannii infections: A 2year prospective study in a Greek surgical intensive care unit. Am J Infect Control 2010;38:631-635.

23. Craven DE, Kunches LM, Lichtenberg DA, et al. Nosocomial and fatality in medical surgical intensive care unit patients. Arch Intern Med 1988;148:1161-1168.

24. Mahzounieh M, Khoshnood S, Ebrahimi A, Habibian S, Yaghoubian M. Detection of Antiseptic-Resistance Genes in Pseudomonas and Acinetobacter spp. Isolated From Burn Patients.Jundishapur. J Nat Pharm Prod. 2014;9(2):e15402.

25. Navaneeth BV, Belwadi MR. Antibiotic resistance among gram negative bacteria of lower respiratory tract secretion in hospitalized patients. Indian J Chest Dis Allied Sci. 2002;44:173-6.

26. Datta P, Rani H, Chauhan R, Gombar S, Chander J. Health-care-associated infections: Risk factors and epidemiology from an intensive care unit in Northern India.Indian J Anaesth. 2014;58(1):30-5.

27. Richards MJ, Edwards JR, Culver DH, et al. Nosocomial infections in medical intensive care units in the United States. National Nosocomial Infections Surveillance System. Crit Care Med 1999;27:887-892.

28. Chelazzi C, Pettini E, Villa G, De Gaudio AR. Epidemiology, associated factors and outcomes of ICU-acquired infections caused by Gram-negative bacteria in critically ill patients: an observational, retrospective study.BMC Anesthesiol. 2015;15:125.

29. Kumari HB, Nagarathna S, Chandramuki A. Antimicrobial resistance pattern among aerobic gram-negative bacilli of lower respiretory tract specimens of intensive care unit patients in a neurocentre. Indian J Chest Dis Allied Sci 2007; 49: 19-22.

30. Falagas ME, Karveli EA, Siempos II, Vardakas KZ. Acinetobacter infections: a growing threat for critically ill patients. Epidemiol Infect. 2008 ;136(8):1009-19. 